\title{
À FLOR DA PELE: ESTUDO ANTROPOLÓGICO SOBRE A PRÁTICA DA TATUAGEM EM GRUPOS URBANOS1
}

\author{
Débora Krischke Leitão ${ }^{2}$ \\ Cornelia Eckert (orientação)
}

\section{Introdução}

O homem, ao longo dos tempos e nas diferentes culturas, sempre marcou o corpo, senão com a tatuagem que conhecemos hoje, com a pintura, as escarnificações e a maquiagem. O body art não é, portanto, um fenômeno novo.

Atualmente, entretanto, caminhando por qualquer rua de qualquer grande cidade é possível identificar a tatuagem estampada na pele de braços, pernas e costas de pessoas das mais diferentes idades, profissões e classes sociais. A tatuagem de modo geral esteve, entretanto, até pouco tempo restrita a alguns grupos tidos como marginais na sociedade ocidental contemporânea. Ela passa hoje a aventurar-se em outros corpos e a colonizar outros mundos.

A cidade de Porto Alegre, contexto em que esta pesquisa foi desenvolvida, conhece a expansão do mercado da tatuagem. O número de novos estúdios comerciais de tatuagem (atendendo ao público em geral) teve um crescimento expressivo nesta última década, os estúdios antigos correm em busca de modernização e a clientela torna-se cada vez maior e mais variada.

Busca-se assim problematizar a tatuagem sob o prisma da Antropologia, situando nossos objetivos em uma interface entre o que se pode chamar de Antropologia do Corpo e Antropologia Urbana, uma vez que pensando o tema em um universo como Porto Alegre, faz-se uma reflexão sobre as formas singulares que os habitantes do mundo urbano marcam seus corpos no sentido de situar ethos e habitus (GEERTZ:1989) que estetizam o viver na cidade.

Visando dar conta da natureza do tema proposto, o método qualitativo de pesquisa, mais especificamente o método antropológico, foi utilizado no presente trabalho. O método antropológico (sobretudo através de seu principal instrumento, a observação participante) pressupõe uma relação de proximidade e interação entre

\footnotetext{
1 Trabalho de conclusão apresentado em Dezembro de 2000, no curso de Ciênciais Sociais da Universidade Federal do Rio Grande do Sul, realizado sob orientação da Prof ${ }^{\mathrm{a}}$. Dr ${ }^{\mathrm{a}}$. Cornelia Eckert.

${ }^{2}$ Licenciada em Ciênciais Sociais e mestranda em Antropologia Social na UFRGS.
} 
pesquisador e pesquisado, quebrando os limites estanques entre sujeito e objeto. Instaura-se assim, uma perspectiva reflexiva e intersticial - olhar desde dentro, (GONÇALVES DA SILVA, 1994:8) dado o lugar do pesquisador (sujeito da pesquisa, mas também objeto, enquanto membro de uma sociedade, de uma cultura, compartilhando experiências e sentidos) no grupo (de sujeitos) pesquisado. Há, então, um processo interativo de pesquisa que, diferentemente dos métodos unicamente quantitativos, "não é um processo acumulativo e linear, cuja freqüência, controlada e mensurada, autoriza o pesquisador, exterior à realidade estudada e dela distanciado, a estabelecer leis e prever fatos" (CHIZZOTTI:1998).

Ainda refletindo a respeito dos pressupostos metodológicos da pesquisa antropológica, é preciso ver a própria noção de objeto como construto, e ter em mente que sua construção parte do pesquisador. O objeto é, antes de tudo, um produto do pensamento. Pierre Bourdieu, citando Saussure, diz que "o ponto de vista cria o objeto" (BOURDIEU:1985). A construção do objeto se dá assim a partir do lugar do pesquisador enquanto sujeito histórico e cultural e de seus pressupostos teóricos. Existe entretanto, na Antropologia, justamente por estarmos lidando com objetossujeitos, a tendência de que o objeto tome forma (ou muitas vezes se modifique) em campo, durante o próprio processo de pesquisa (LÉVI-STRAUSS:1997b).

Foram realizadas entrevistas individuais e abertas com dez tatuados pertencentes as camadas médias de Porto Alegre, cuja faixa etária variava de 18 à 43 anos. As entrevistas individuais tiveram como cerne um roteiro de tópicos de interesse, e foram realizadas tanto na casa dos entrevistados quanto em lugares públicos - como o Parque da Redenção ou a praça de alimentação de um shopping. A escolha dos entrevistados seguiu o critério de que todos eles deveriam ter mais de uma tatuagem. Não houve uma seleção de gênero, tanto homens quanto mulheres tatuadas foram incluídas na rede de informantes. Dos dez entrevistados, temos que quatro são mulheres (de 18 a 34 anos) e seis são homens (de 21 a 43 anos). Todos eles pertencem a camadas médias da cidade de Porto Alegre e têm segundo grau completo. 


\section{Tatuagens, histórias e estórias}

\section{Breve histórico da tatuagem no mundo:}

O mais antigo homem achado intacto, datado de 5300 a.C. e conhecido como o Homem de Gelo, tinha o corpo marcado: tatuagens na região lombar, no joelho esquerdo e no tornozelo direito (MARQUES:1997). Depois dele, no antigo Egito, temos notícia de uma grande quantidade de múmias tatuadas, a começar pela princesa Amuet, da XI Dinastia, cujo ventre era desenhado com linhas e pontos construindo uma forma elíptica, associada a ritos de fertilidade. Heródoto relata também, em sua História $^{3}$ citas, trácios e tebanos marcados com escarnificações e desenhos cicatriciais pigmentados.

É através das primeiras viagens marítimas, entretanto, que temos maior notícia do passado da tatuagem. Marco Polo, vê em suas viagens e escreve em suas descrições da Ásia do século XIII, o colorido da tatuagem no continente asiático (CARUCHET:1995), especialmente em uma província conhecida como Cancigu, situada em algum lugar entre o que hoje é a Birmânia e a Tailândia. Lá, segundo Marco Polo, era comum cobrir o corpo todo com desenhos indeléveis de leões, dragões, pássaros e outras figuras.

Também Cristóvão Colombo e Américo Vespucio introduzem em seus relatos a questão da pintura corporal (nem sempre tatuagem) nas sociedades americanas. Os relatos de Américo Vespúcio, tratando especialmente do Brasil, fazem referência a modificações no rostos dos nativos, incisões, perfurações e sobretudo adornamento dessas perfurações com, segundo ele pedras preciosas (CARUCHET:1995).

A primeira grande "revolução" da tatuagem vai se dar com outro viajante, ainda que apenas no século XVIII. Em 1769 o capitão James Cook, em viagem pelo Taiti descobre a tatuagem. É graças a ele que a palavra tatuagem (tattoo) entra para a língua inglesa, através de uma adaptação sua para as palavras taitianas e samoanas "tatah" e "tah-tah-tow", que significavam marcar o corpo (KRAKOW:1994). Do pacífico assim veio a arte e a palavra introduzidas na europa.

Os Maori da Nova Zelândia desenhavam elaboradas tatuagens faciais (makule) que, formadas por linhas e arabescos diversos, simbolizavam a família, a

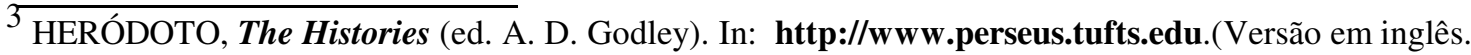
Contido biblioteca digital de textos clássicos do Perseus Project.) 
descendência, a região de origem e as conquistas da pessoa. (CARUCEHT:1995). Diz William Caruchet, em seu livro "Le tatouage, ou le corps sans honte" que quando os europeus que lá chegaram pediam aos Maori que assinassem documentos, obtinham, no lugar de nomes ou assinaturas desenhos idênticos às tatuagens, que, na realidade, significavam para os nativos seus nomes, quem eles eram.

Quando Cook volta à Europa, em 1775, leva consigo um homem polinésio chamado Omai, que tinha o corpo completamente tatuado (RUBIN:1988). É em parte graças a Omai que a tatuagem chega à Europa, virando acessório de cavalheiros da aristocracia. Estes, entretanto, longe de tatuar em seu corpo marcas semelhantes as dos maori, faziam uso de figuras de dragões e emblemas de nobreza em seus braços e costas (PUELLES:1998).

Ainda no século XVIII desenvolve-se na Europa uma mania um tanto macabra: colecionar cabeças maori tatuadas. O valor de troca das cabeças tatuadas era equivalente a uma determinada quantidade de armas fornecidas pelos europeus aos polinésios. Com o tempo, a procura pelas cabeças e o desejo dos maori em trocá-las por armas era tão grande que cada inimigo de guerra e escravo era morto e tinha sua cabeça tatuada para ser vendido. O governo inglês resolve então tomar uma medida legal, proibindo a "importação de cabeças humanas" (RUBIN:1988).

No fim do século XIX a era das máquinas modifica o mundo ocidental em todos os setores. Novos aparelhos revolucionam o transporte e a produção. É nesse contexto que a tatuagem também se transforma, tornando-se mecanizada.

Durante milhares de anos eram feitas tatuagens com ferramentas manuais, um processo dolorido e demorado, que poderia durar semanas, meses e até anos. Com a invenção da primeira máquina tecnológica de tatuar, criada em 1891 por O'Reilly em Nova Iorque, o processo se torna mais rápido e mais popular (CARUCHET: 1995). Tatuagens feitas em apenas algumas horas e com muito menos dor fizeram surgir lojas de tatuagem por toda a América do Norte. Os desenhos prontos eram vendidos por toda parte e a habilidade do artista não era mais tão necessária, uma vez que as figuras eram facilmente copiadas.

Com esse conjunto de mudanças a tatuagem se torna acessível à um número muito maior de pessoas. Mas se por um lado ela se populariza, por outro fornece 
material para a criação de uma onda da atração pelo exotismo exagerado. É assim que a tatuagem logo se torna atração de circos, parques de diversões e feiras. Pessoas exibem seus corpos completamente tatuados e nus para um público que se delicia com o espetacular e o extraordinário (MIFFLIN:1997). No final dos anos vinte mais de trezentas pessoas totalmente tatuadas trabalham em circos americanos. De todas as performances, as femininas eram as que mais agravam. Por conta disso se espalham dezenas de "mulheres tatuadas" pelo país, como as famosas Betty Broadbent, Trixie e a Belle Irène. Existia entretanto outras modalidades de espetáculo, com homens, casais e até mesmo famílias tatuadas (SCHIFFMACHER:1996).

Nos 50 anos seguintes a tatuagem continuou a ser símbolo das classes marginais. Marinheiros, prisioneiros e soldados de guerra voltavam para casa tatuados. No caso do prisioneiros, marcas simbolizando o crime cometido e o tempo de prisão (SCHIFFMACHER:1996). Soldados traziam na pele outro tipo de motivos, como emblemas patrióticos e nacionalistas. Muitos tatuadores até mesmo viajavam nos navios junto aos marinheiros (CARUCHET:1995).

Além de marinheiros e artistas de circo, a tatuagem enfeitou a pele de algumas mulheres nos anos 40 e 50. Eram pin-ups ou mesmo senhoras de família (estas mantendo suas tatuagens bem escondidas dos olhos alheios) que, altamente tatuadas, eram chamadas de atomic ladies (MIFFLIN:1997).

Os anos 60 e 70 inserem a tatuagem no mundo da contracultura de da indústria pop. O movimento pacifista dos hippies e a cultua Rock'n'Roll foram férteis para os que queria tatuar corpo. Mas a tatuagem ainda estava, de alguma forma, à margem, e em certa medida simbolizava uma forma de protesto social (SCHIFFMACHER:1996).

A partir dos corpos de gente famosa, artistas, músicos, atores (Joan Baez, Janis Joplin, Sean Conery, e David Bowie são, entre tantos outros, tatuados) acabou sofrendo transformações até tornar-se socialmente aceitável em quase todos os círculos. Entre os tatuados famosos do século XX estão Charles Chaplin, os cantores Tom Waits e Johnny Haliday, o pugilista Mike Tyson, os atores Michkey Rourke e Gérard Dépardieu e as atrizes Beatrice Dale, Melanie Griffith e Cher.

$\mathrm{Na}$ literatura internacional, a tatuagem aparece em obras de grande reconhecimento. A peça de Tenesse Williiams, Rosa Tatuada é um exemplo disso. 
Também em Flaubert as tatuagens cartagineses aparecem no romance Salambô, no corpo de guerreiros e prisioneiros. Kafka em, Na Colônia Penal traz a máquina fantástica que tatua a sentença no corpo do acusado, de acordo com o crime que este cometeu. Este não sabe, entretanto, qual é seu crime e menos ainda seu destino. Em momento algum isso deve ser dito através de palavras. É na pele, nos desenhos que a máquina fará em sua costas, que ele saberá. Em Cem Anos de Solidão de Gabriel Garcia Márquez um dos personagens, um dos José Arcádios que povoam a Buendía e o romance, vai embora de Macondo com os ciganos e, quando volta, traz o corpo todo bordado de tatuagens, encantando as mulheres da cidade.

No cinema, em $O$ pecado mora ao lado, Charles Lederer, o marido que é deixado pela esposa (que sai de férias sozinha) à mercê dos encantos da vizinha, tatuase na ausência da mulher. Mais recente, o filme Foxfire, protagonizado pela atriz Angelina Jolie, a mais famosa atriz tatuada da atualidade (e provavelmente a mais tatuada atriz, com 7 desenhos espelhados pelo corpo). O filme conta a história de um grupo de cinco ou seis moças que, para simbolizar sua união, tatuam uma "chama", uma "labareda" no peito. Perter Greenway também tem um belo filme a propósito dos desenhos no corpo, é o Livro de Cabeceira, cuja personagem principal, uma jovem oriental, tem a escrita sobre o corpo com uma obsessão e estímulo erótico.

Nos desenhos animados, não há quem não lembre do marinheiro Popeye, com sua tatuagem de âncora no antebraço e, na pintura, o mais famoso aparecimento da tatuagem é em um quadro de Norman Rockwell, que retrata um marinheiro sendo tatuado.

Atualmente a técnica da tatuagem vem sendo usada para uma série de outras práticas. Um exemplo disso é a maquiagem definitiva, que usa o mesmo princípio de pigmentação, ou a coloração de manchar e cicatrizes. Já utilizado hoje também é o método de identificação rápida do tipo sangüíneo através da escrita deste no corpo, através de uma tattoo. (SCHIFFMACHER:1996). A partir dessa "identificação" através da marca externa houve a sugestão por parte de alguns grupos de extremadireita que que fosse obrigatório aos portadores do vírus do HIV usar marca semelhante, identificando-os através do desenho/escrita em seu corpo. É uma sugestão que certamente conduziria a segregação de um grupo de "doentes", frente aos "sadios", 
e que em muito se assemelha ao horror da marcação de judeus nos campos de concentração.

\section{Breve histórico da tatuagem no Brasil: ${ }^{4}$}

A tatuagem moderna chega a nosso país em algum ponto do século XIX, trazida por marinheiros ingleses e americanos às cidades portuárias. Ela vem parar em nossos portos assim como parou em quase todos os portos do mundo. Vai passando assim, como uma moda, entre marinheiros e, ainda no porto, também pelas prostitutas, muitas tatuadas.

A palavra tatuagem entra para a Língua Portuguesa antes mesmo do fim do século XIX, registrada no "Novo Dicionário da Língua Portuguesa", de Candido Figueiredo, editado em 1889 em Lisboa.

A tatuagem se espalhou rapidamente. Não existiam aqui tatuadores fixos, apenas aqueles que vinham com os navios, ficando um curto espaço de tempo em solo brasileiro.

Para a polícia do Rio de Janeiro sua expansão era vista como expansão da marginalidade e criminalidade. No princípio do século XX a tatuagem era considerada uma das provas de culpabilidade de um acusado, de acordo com as teorias de médicos criminalistas europeus, como Lombroso.

Por muito tempo, entretanto, tivemos apenas esses tatuadores "nômades", que vinham, trabalhavam algum tempo no porto, ganhavam algum dinheiro e logo partiam. Foram americanos, escandinavos, ingleses, gregos, e artistas de muitas outras nacionalidades.

O primeiro tatuador a se estabelecer no Brasil foi Lucky, na época conhecido como Mr. Tattoo, um dinamarquês que aqui chegou em julho de 1959. Até a primeira metade da década de setenta, entretanto, Lucky é o único tatuador profissional da América Latina, como avisa o jornal O Globo em 04 de dezembro de 1975.

É nos anos 70 que a tatuagem deixa os portos e o mundo marginal, mas permanece perto do mar. Ela vira então mania entre os jovens da Zona Sul do Rio de Janeiro, a chamada "juventude dourada". Pode ser vista a partir daí cada vez com mais

\footnotetext{
${ }^{4}$ Este subcapítulo foi concebido a partir do livro "O Brasil Tatuado e outros mundos", de Toni Marques.
} 
freqüência nas praias do Rio, no corpo exposto e bronzeado dos "tatuados de Ipanema", uma geração marcada pelo estilo de vida ligado à natureza, ao uso de drogas leves e ao surfe.

Lucky passa a ter outra freguesia, porque os tatuadores profissionais por muito tempo continuam nos portos, não se aventurando a ganhar as cidades. Muitos jovens do Rio iam até Santos para se tatuar com Lucky.

Os grandes veículos de divulgação da tatuagem na época foram os corpos dos surfistas (especialmente de Petit, imortalizado por Caetano Veloso como o "menino do Rio") e a Revista Pop, publicação da Editora Abril direcionada à juventude dourada dos anos 70 .

É através da voz de Baby Consuelo que a música de Caetano, hino de uma geração, transforma a tatuagem em algo socialmente aceitável, e até certo ponto desejável. A música do "menino do Rio", e seu "dragão tatuado no braço" viram mesmo música tema da novela Água Viva, da Rede Globo.

A moda da tatuagem não foi entretanto exclusividade da juventude dourada, chegando em 1977 ao movimento punk que surgia na periferia de São Paulo.

Com o aumento excepcional da procura pelo serviço de tatuadores, mais profissionais estrangeiros chegam ao país, assim como tatuados brasileiros aprendem o ofício, alguns ainda tatuando através do processo manual, com agulha e nanquim. É a década de oitenta que marca a profissionalização dos tatuadores.

A primeira loja de tatuagem moderna do Rio de Janeiro, localizada estrategicamente em uma galeria da rua Visconde de Pirajá, surge em março de 1980 e pertence a uma mulher: Ana Velho, a primeira tatuadora do país. A loja, grande e com muito conforto, ar condicionado, bela decoração e boa localização, não atrai apenas a garotada das praias mas todo tipo de gente.

O reconhecimento da profissão de tatuador só vai acontecer nos anos 90, quando já há, em quase todas as cidade dos país, oficialmente, estúdios qualificados e, informalmente, os tatuadores de nanquim e agulha que até hoje executam trabalhos pelas ruas. 


\section{O Corpo na Antropologia}

Tomar a tatuagem como objeto de análise da antropologia é apenas possível se a própria noção de corpo for apreendida como fenômeno não apenas natural mas histórico e cultural. O homem e seu corpo são, antes de tudo, uma realidade palpável, e talvez seja justamente essa concretude que imponha por vezes barreiras à sua relativização. Todos temos um corpo em primeira instância sentido como físico, biológico e natural. E é a partir do pressuposto do natural, do inato, que deixamos para trás suas outras dimensões.

O corpo do homem é, na realidade, vivido e pensado de diferentes maneiras, inserido em um tempo e um espaço. Cada forma particular de "habitar" um corpo, os usos dados a este corpo no mundo, o próprio corpo enquanto ente, enquanto matéria, no entanto, também vão estar reconstruindo esse tempo e esse espaço.

Existe, assim, um imenso leque de possibilidades, de formas de se lidar com o corpo e de relações entre os sujeitos, seus corpos e o mundo. Os diferentes padrões de ritmos de vida, formas de repousar e até mesmo manifestar - e por que não sentir?cansaço, põe a prova a naturalidade - na realidade tão pouco natural - da sociedade ocidental. Guiados por nossas "máquinas de calcular o tempo", em muito nos diferenciaríamos das chamadas "sociedades musculares" (BASTIDE:1983), muito mais guiadas por seus ritmos fisiológicos do que nós, com nossos momentos de cansaço previstos de antemão.

Outros tantos comportamentos naturalizados se encontram fundamentados em alicerces culturais, mais do que da esfera do biológico. Mesmo na prioridade que damos ao uso da mão direita em detrimento da esquerda poderíamos encontrar a transposição de um antagonismo existente no mundo da cultura para o âmbito corporal. Se em toda parte existe a oposição hierárquica entre bom e mal, belo e feio, forte e fraco, sagrado e profano, como não haveria também no corpo do homem essa mesma hierarquia? (HEERTZ:1980) Se realmente existe uma assimetria dada a nível fisiológico, o que se faz, convém notar, é reforçá-la. A mão direita - domínio do bom, do sagrado, do viril- ainda que tida como naturalmente mais dotada de força, é aquela que recebe melhor treinamento, ao passo que a esquerda - fraca e perigosa - é mutilada, se não em sua aparência, em sua função. 
As diferenças encontradas, de uma sociedade para outra, na forma de usar o corpo reforçam, acima de tudo, seu fundamento cultural. As diversas formas de caminhar, de nadar, de comer, de higiene e até mesmo de parir devem ser compreendidas como parte de um habitus (MAUSS:1997) que, de natureza social, configura os múltiplos elementos da arte de utilizar o corpo. A cultura seria de importância fundamental na determinação de gestos e posturas corporais, estando estes vinculados a um aprendizado.

Haveria assim, segundo Mauss, uma série de "atitudes corporais" próprias a cada sociedade. O autor nos traz, em seu escrito sobre as técnicas corporais, uma coletânea de exemplos nesse sentido. O onioi, uma espécie de caminhar rebolado comum - e valorizado - entre as mulheres Maori é uma boa ilustração. Prática que seria incomum e até mesmo ridícula entre nós, é passada de mãe para filha, como uma arte, na sociedade Maori e, uma vez adquirida, passa a ser uma maneira natural de caminhar.

Assim como o onioi, todas as outras técnicas corporais - e Mauss fala do corpo como técnica, porque primeiro instrumento do homem- seriam transmitidas através da eficácia da tradição. Uma vez incorporadas, como costumes, se prenderiam tão fortemente ao homem que nem mais poderiam ser por ele percebidas.

Além das atitudes corporais apreendidas, o aspecto externo do corpo do homem vai ser modificado de acordo com parâmetros culturalmente definidos. LéviStrauss nos diz, a respeito dos Canduevo, que para ser homem era preciso ser pintado (LÉVI-STRAUSS, 1997b:216). Uma vez decorado, vestido e pintado o homem exibiria sua humanidade. Desde seu nascimento tem impressos em seu corpo os caracteres da cultura (o habitus de que nos fala Mauss), através de comportamentos e sentimentos adequados e aceitos, de uma língua, de um jeito de vestir, entre tantas outras formas de tornar-se "humano".

As modificações corporais são assim, de maneira bastante visível, parte desse formar, deformar e conformar o corpo (biológico, individual, social e cultural) do homem (BOREL, 1992:15). Essas modificações, mesmo que também com objetivos estéticos, podem ser consideradas o que Michel de Certeau chama de adaptação do 
corpo à um código, a uma norma (da cultura), constituindo o "retrato físico". (DE CERTEAU:1996:240).

Pierre Clastres, analisando a tortura nas sociedades tribais, também pensa no corpo como superfície de escrita. Segundo ele, do rito de iniciação o que resta, com o tempo, é a marca, as cicatrizes e desenhos deixados na pele do iniciado. (CLASTRES:1990). É o corpo o mediador do saber aprendido durante a iniciação. A lei escrita sobre o corpo do homem é a lei do grupo, e ser um homem marcado é, em grande medida, proclamar da forma mais visível possível seu pertencimento a ele.

Viveiros de Castro trata do conceito de corpo fabricado (VIVEIROS DE CASTRO) entre os Yawalapiti, para os quais o corpo só é humano quando submetido a processos intencionais e periódicos de construção. A noção de "fabricar um corpo", nessa sociedade, está principalmente relacionada com os processos envolvidos na concepção, ou melhor, na própria concepção como processo, composta por momentos diferentes e não se restringindo ao instante da fecundação. É interessante pensar, entretanto, a possibilidade dessa noção de construção de corpo ser tomada da forma como é entre os Yawalapiti. Para eles, as transformações no corpo estão relacionadas comumente à mudanças de identidade, mas nunca vistas nem como índices nem como símbolos delas. As mudanças corporais e as modificações sociais são, para os Yawalapiti, uma única coisa.

O corpo construído, objeto da lei da sociedade e da cultura, pensado por Clastres e por Viveiros de Castro é, entretanto, um corpo diferenciado do corpo tatuado e urbano com o qual estamos lidando aqui. Ainda que o conceito de construção do corpo seja fundamental para se pensar as marcas corporais da sociedade contemporânea, há de se atentar para as diferenças entre a idéia do corpo "igual" da sociedade tribal (CLASTRES:1990) e o corpo idealmente individualizado de nossa sociedade.

Me refiro aqui ao corpo em nossa sociedade urbana ocidental e contemporânea como "individualizado", de acordo com a conotação dada ao termo por Dumont, quando o autor diz ser o "individualismo" a ideologia que predomina na sociedade ocidental moderna (DUMONT:1997). 
Segundo o autor, nesse caso, em vez da sociedade ser pensada enquanto totalidade (como se dá nas ditas "sociedades holistas"), tomamos cada indivíduo como uma totalidade indivisível, cada indivíduo passa a ser a medida de todas as coisas.

Dumont estabelece uma comparação entre a sociedade ocidental e a sociedade indiana, de castas, fundada no princípio da hierarquia. A sociedade indiana poderia ser considerada uma sociedade holista, em contraposição a sociedade individualista, na qual a idéia da busca de interesses individuais predominaria. A ideologia individualista supõe que cada indivíduo carregue em si a essência da humanidade, seja uma síntese de toda a sociedade. Para ele, o indivíduo como valor é uma criação histórica, que teria germinado com o cristianismo, e se estabelecido definitivamente com Calvino (DUMONT:1985).

A noção de indivíduo como algo sagrado, auto-suficiente e independente do grupo seria, assim, uma das características da modernidade ocidental. Nas sociedades tradicionais o homem se encontraria submisso a forças impessoais, na modernidade a vontade individual se torna mais importante do que qualquer destino. O sujeito humano emerge como sujeito livre e sujeito criador. A idéia de igualdade e de liberdade estão profundamente arraigadas a de indivíduo. Segundo Alain Touraine, as duas categorias fundantes dos tempos modernos seriam a de Racionalidade e de Subjetividade (TOURAINE:1992), categorias aparentemente contraditórias mas que, como o Renascimento e a Reforma, se completariam mutuamente.

O homem se propõe a cientificidade e a racionalidade objetiva, mas também faz questão de afirmar-se enquanto sujeito e subjetividade. A criação do sujeito seria, antes de tudo, a criação de um mundo em que tudo é regido por leis racionais e inteligíveis pelo pensamento humano. O princípio e valor central do mundo, antes depositado na religião e em uma moralidade religiosa, passa a ser liberdade. Com a Revolução Francesa esse ideário de liberdade e igualdade se afirmam, e a idéia de direitos individuais vai, a partir da declaração universal dos direitos do homem e do cidadão, se tornar inquestionável. A noção de sujeito livre traz consigo a superioridade das virtudes privadas sobre os papéis sociais, e da consciência moral sobre o julgamento coletivo. 
É a idéia do homem livre e senhor de suas vontades que dá sentido às proposições de David Le Breton a respeito das modificações corporais. Segundo ele, na modernidade, a anatomia original deixa de ser um destino, e o indivíduo tem a possibilidade de agir sobre seu corpo como um bricoleur. (LE BRETON: 1999).

A tatuagem e o piercing, assim como a cirurgia plástica e mesmo as operações de mudança de sexo marcariam o momento alto de dominação do homem sobre seu corpo que, graças aos avanços científicos torna-se relativamente maleável e sujeito a modificações. O corpo biológico estaria, assim, subordinado a uma vontade (racional, emocional, etc...) do indivíduo. Essa subordinação só é possível, entretanto, se as noções de corpo e de alma (ou mente) forem tomadas como entidades separadas.

Pensar o homem separado de seu corpo significa então pensar na oposição entre corpo e alma/mente, entre matéria e espírito. Tal separação não existia, entretanto, na idade média, quando tanto o corpo quanto a alma, considerados um só coisa, tinham caráter sagrado (RODRIGUES:1999). Se explicaria assim, por exemplo, a adoração de partes dos corpos dos santos, que mais do que uma representação, seria uma materialização que remete à coisa divina, era o sagrado em si. A dessacralização do corpo e sua separação da alma individual são na verdade um único e mesmo processo. É então apenas após Descartes, quando se estabelece enfim a oposição entre carne e espírito que o corpo, deixando de ser sagrado, pode passar a ser um objeto de estudo como qualquer outro. É apenas depois de separado da alma que o corpo pode ser aberto pelos primeiros anatomistas.

Considerada essa dimensão individual, em que os sujeitos modificam sua aparência física de acordo com seu desejo e vontade, é preciso de alguma forma dar conta de uma tensão que se faz presente na relação estabelecida entre indivíduo e sociedade, eu e os outros. ${ }^{5}$

Gilberto Velho fala da sociedade complexa urbana e ocidental como uma sociedade na qual as noções de biografia e de projetos individuais são centrais (VELHO:1994). Tais noções, entretanto, são permeadas pelo conflito entre individualização (autonomia do sujeito) e totalização (lugar do sujeito no grupo social), sendo impossível pensar o projeto como um fenômeno puro, interno ao

\footnotetext{
${ }^{5}$ Ver capítulo V
} 
indivíduo. As ações individuais estariam assim, inscritas num campo de possibilidades, e relacionadas histórica e culturalmente.

Jean-Thierry Maertens, escrevendo sobre a tatuagem, a relaciona diversas vezes ao "olhar do outro" (MAERTENS:1978), comparando-a à maquiagem feminina (em oposição as cicatrizes masculinas). David le Breton, no mesmo sentido, fala no ato de atrair o olhar (LE BRETON:1999). Segundo o autor, a tatuagem e as outras formas de body art (piercing e pintura corporal não-permanente, por exemplo) teriam em si a capacidade de fabricar uma estética da presença.

Quando Gilberto Velho fala do projeto individual ocupando um lugar histórico e cultural, diz que esse projeto não é totalmente interno ao sujeito porque é preciso que seja transmitido e, portanto, de alguma forma compartilhado (VELHO: 1987). Ele é compreendido por aqueles que compartilham o mesmo estilo de vida, mas também pelo resto da sociedade.

\section{Desenhando Contornos}

A pesquisa teve início no primeiro semestre do ano de 2000, quando começou a ser mapeado o universo de pessoas que seriam entrevistadas. Era necessário que fossem definidos então alguns critérios de escolha dos primeiros entrevistados. $\mathrm{O}$ primeiro deles obviamente, era de que fossem tatuados.

Através de um programa de conversação na Internet, que permite buscar usuários do programa utilizando filtros - selecionando a faixa etária desejada, a cidade / país de residência, o sexo ou alguns interesses específicos - procurei por pessoas que morassem em Porto Alegre e tivessem colocado entre seus interesses a tatuagem. Das pessoas que contatei, apenas uma, Luisa, respondeu minha mensagem. Conversamos algum tempo ainda através da internet e ela aceitou me encontrar para que pudesse entrevistá-la.

A primeira entrevista com Luisa aconteceu em um Sábado, em sua casa, no bairro Cidade Baixa, onde pude conhecer também sua mãe (que tem duas tatuagens). Luisa tem 23 anos e fez sua primeira tatuagem aos 18: um índio na perna. Além dessa, tem mais duas, dois dragões, um no pé e outro no braço. Depois de entrevistar Luisa fotografei suas tatuagens e ficamos olhando alguns livros de fotografias de tatuagem que eu havia levado comigo. Sua mãe não quis ser fotografada, e me 
mostrou apenas uma de suas tatuagens, alegando que a outra era "muito velha, toda desbotada".

Interessada pelo tema, Luisa se dispôs a me apresentar outras pessoas tatuadas de sua rede de relações, sobretudo pessoas que trabalham com ela na Secretaria Municipal de Cultura. Me passou o número do telefone de três deles. Combinamos entretanto que ela faria um primeiro contato e só depois disso eu os procuraria.

Já na manhã seguinte recebi seu telefonema: ela havia marcado um encontro com Zé, seu amigo de infância e antigo vizinho de quando vivia na cidade de Guaíba. Também tinha telefonado à Helô e combinado que eu ligaria para sua casa à noite.

Conheci Zé então em uma tarde de Domingo, no parque da Redenção. Quando chegamos o rapaz estava deitado no gramado em frente ao auditório Araújo Viana, fumando e escutando música. Num primeiro momento conversamos os três, Zé, Luisa e eu. Depois, sozinha com Zé, pude entrevistá-lo e fotografar suas tatuagens.

Zé tem 25 anos e mora em Guaíba com os pais, onde trabalha em uma farmácia. Passa entretanto a maioria dos finais de semana em Porto Alegre, sempre envolvido com festas e principalmente com shows de reggae. Tem cerca de seis tatuagens, todas com motivos que chama de "tribais" ou "balineses".

A entrevista com Helô foi marcada, então, a partir de meu telefone. Ela pediu que eu a encontrasse na praça de alimentação do Shopping Moinhos, situado no bairro Moinhos de Vento, bairro considerado de classe média alta da cidade de Porto Alegre.

Helô tem 34 anos, é formada em Artes Plásticas pela UFRGS e é professora de pintura para crianças, em uma "escolinha" próxima dali. Casada e sem filhos, mora na rua Felipe Camarão, bairro Bonfim, com a família do marido. Conhece Luisa da Secretaria Municipal de Cultura, onde fez cursos no "ateliê livre", e onde Luisa trabalha na Coordenação de Artes Cênicas.

Da rede de relações de Luisa conheci ainda Caco, um rapaz de 26 anos. Ele conta ter feito sua primeira tatuagem aos 15 anos, e quando pergunto quantas tem agora responde "um montão, umas doze ou mais". Além das tatuagens tem os cabelos pintados de verde e "embaraçados" em um estilo "rastafari".

A entrevista com Caco aconteceu também no parque da Redenção, no mês de junho. Além de Luisa como intermediária do encontro, Helô também mencionou 
Caco, insistindo que eu entrevistasse o rapaz, também seu conhecido por ter trabalhado com Luisa na Secretaria.

Caco mora no bairro Rio Branco, com os pais. Ele estuda publicidade mas é muito envolvido com música. Diz "montar o som" em shows de bandas da cidade.

Mais um conjunto de entrevistas aconteceu com pessoas que me foram direta ou indiretamente apresentadas por Marco e Fábio, dois tatuadores. Marco foi o primeiro que conheci, em uma tarde de Domingo, na Usina do Gasômetro, por ocasião do Mix Bazar -feira de variedade que acontece periodicamente na cidade, sediada na Usina do Gasômetro ou em um dos armazéns do cais do porto.

Na saída da feira, já perto do entardecer, encontrei uma amiga em frente a Usina e paramos para conversar. Junto à ela estava um rapaz com os braços cobertos de tatuagem. Ele usava bermuda, tênis e uma camiseta pintada, tinha piercings na orelha e na língua. Conversávamos sobre a feira, onde por vezes tatuadores alugam stands e oferecem seu serviço ao público. Minha amiga então comentou que Marco era tatuador, e eu manifestei interesse em entrevistá-lo. Ele me deu seu cartão de visita e prometi aparecer no estúdio de tatuagem onde trabalhava para que pudéssemos conversar.

Duas semanas depois fiz minha primeira visita ao estúdio. Lá, além de Marco, trabalhava Fábio. Os dois tatuam a cerca de cinco anos e, além de tatuar, trabalham fazendo grafite.

Pretendia a princípio apenas estabelecer contatos individuais e ter nos tatuadores uma ponte e via de acesso a pessoas que fossem tatuadas (mas não tivessem a tatuagem como profissão). Acabei entretanto optando igualmente pela observação participante no estúdio de Fábio e Marco.

Meu lugar no estúdio era diferente do que ocupava nas entrevistas individuais, por essa razão considerei fundamentais as tardes de observação. Se nos primeiros dias eu era "a Débora, que pesquisa tatuagem e estuda Ciências Sociais", em pouco tempo era (para os clientes), a amiga dos tatuadores, digna de confiança e que também deveria ser considerada quando eram feitas perguntas a respeito das tatuagens.

Digo que minha observação no estúdio foi participante na medida em que havia interação, e minha presença no lugar não passava desapercebida. Muitas vezes clientes 
me perguntavam sobre minhas próprias tatuagens, pediam opiniões sobre as que pretendiam fazer, e até mesmo faziam perguntas técnicas (que com o tempo aprendi a responder) a respeito de cuidados e principalmente (as perguntas fundamentais do pretendente a tatuado): "será vai doer?", "verdade que perto do osso dói?", ou " a tua doeu?"

Minha presença no estúdio me permitiu também conhecer outros entrevistados. Antônio, um rapaz de 21 anos foi o primeiro deles. Por ter grande interesse pela tatuagem, aparecia com frequiência no estúdio para conversar e ver revistas de tatuagem importadas.

Antônio tem duas tatuagens e diversos piercings (língua, orelha, mamilos, etc.). Já nos conhecíamos há algum tempo quando propus a entrevista, que foi realizada na sala de espera do estúdio, enquanto os tatuadores trabalhavam em uma sala separada.

Assim como Antônio, Karen, sua namorada, também freqüenta o estúdio. É cliente de Fábio e Marco, mas sempre que eu a encontrava por lá estava "a passeio", "só pra dar um oi", ou "pra jogar conversa fora", como ela dizia. A entrevista com Karen foi feita em seu apartamento, no centro da cidade, onde ela vive com uma amiga. Ela trabalha em uma loja de roupas na Avenida Independência, próxima ao estúdio, por conta do que diz estar "sempre passando por lá". Karen tem quatro tatuagens e, assim como o namorado, vários piercings (língua, nariz e mamilos).

Karen me apresentou Bia, sua colega de faculdade (Jornalismo), também no estúdio. Bia tem 18 anos e duas tatuagens. Nos conhecemos na tarde em que ela fazia sua segunda, e tive oportunidade de conversar com ela por algum tempo, enquanto esperava que Marco terminasse de tatuar outro cliente e pudesse atendê-la.

Bia mora no bairro Petrópolis com os pais, e por ser menor de idade quando fez sua primeira tatuagem, teve que pedir autorização da mãe. A entrevista com Bia aconteceu dois dias depois da tarde em que nos conhecemos, na presença de seu tio, também entrevistado.

Ainda em nosso encontro no estúdio, quando combinei com Bia o encontro em um café da rua Fernandes Vieira (Cave Café), ela me prometeu que levaria o tio, Henrique, de 43 anos. Henrique é arquiteto de formação mas atualmente não trabalha 
mais na área. É empresário, administrando uma empresa no ramo de alimentação. Ele tem três tatuagens, fez sua primeira aos 20 anos, no Rio de Janeiro, quando era surfista. A última foi feita no estúdio de Fábio e Marco.

Tendo começado assim com dois interlocutores que não se conheciam, aos poucos a rede que envolvia seus conhecidos foi se formando e, em alguns pontos, até mesmo se fechando. No desenrolar da pesquisa acabei por descobrir que muitos dos entrevistados (do círculo de relações de Luisa e de Marco e Fábio) se conheciam entre si. Zé e Caco conheciam os tatuadores Marco e Fábio,. Da mesma forma, Antônio e Karen reconheceram as fotos que mostrei de Helô, e disseram já tê-la visto algumas vezes nos bares que frequentam.

A aproximação e concordância dos entrevistados em compartilhar alguns momentos de "troca" foi de aceitação e empatia. Partilhávamos de vivências semelhantes, morando na mesma cidade, estando em uma faixa etária na maioria das vezes semelhante e pertencendo a camadas médias. Penso, entretanto, que o fato de eu também ter tatuagem facilitou a aproximação e o diálogo. Meu papel não era o de alguém "de fora" que se interessa pelo tema. Era, ao contrário, o de alguém disposto a compartilhar experiências, procurando, entretanto, construir esse compartilhar dentro de uma postura crítica, tanto em relação ao grupo com o qual trabalha quanto à si próprio. Uma boa ilustração é uma situação vivida durante o processo de pesquisa, no primeiro contato com Caco, de 26 anos, quando me apresentei e expliquei que tipo de pesquisa estava fazendo, ao que ele respondeu: "Mas tu não vai ser desses que chega e fala mal da tatuagem né?" e que completa, olhos fixos no piercing que tenho no nariz: "Não, claro que não vai... pega meu telefone e a gente conversa."

Além das entrevistas e da observação, a fotografia também foi incorporada como instrumento de análise antropológica. Eu estava lidando, antes de tudo, com imagens, com a idéia de uma "subjetividade" corporificada, impressa na derme, quatro milímetros a dentro, profunda e superficial a um só tempo (como diz Paul Valéry, "le plus profond c'est la peau"), e sobretudo visível. Um famoso tatuador americano, falando da efemeridade da tatuagem, que morre junto com o 
corpo daquele que a carrega, diz que é apenas depois de ser fotografada que a tatuagem se concretiza verdadeiramente.

A maioria dos tatuados que fotografei já havia tido suas tatuagens concretizadas através de uma câmera fotográfica. O meu olhar e o meu lugar ao fotografá-los, entretanto, era outro, e por isso talvez tenham sempre se mostrado dispostos a que eu os fotografasse. A decisão a respeito de como seriam feitas essas fotografias também nasceu do processo de pesquisa. A partir de reflexões e leituras pude ver mais claramente o que pretendia. Minhas pretensões só tomaram corpo realmente com a valiosa sugestão de um amigo: que as fotos fossem feitas não apenas da tatuagem em si, ou da pessoa toda, mas que tentassem refletir o ato de mostrá-la. Meu pedido, que antes era "deixa eu fotografar a tua tatuagem?", passou a ser "deixa eu ver, me mostra a tua tatuagem". Surgiam, assim, camisetas que eram levantadas, calças puxadas para cima, mãos que apontavam para a parte do corpo a ser mostrada e, principalmente, olhares que se direcionavam para o mesmo lugar que minha câmera estava apontada. $\mathrm{O}$ ato de mostrar era quase sempre o ato de olhar para a própria tatuagem que, a seguir, transformava-se no ato de contar as histórias e estórias dessa tatuagem.

\section{Inserindo pigmentos}

Durante as entrevistas, diversos temas (constando ou não no roteiro de questões de interesse) diretamente relacionados a prática da tatuagem e aos significados atribuídos pelos entrevistados às suas marcas foram levantados.

No grupo de pessoas tatuadas que entrevistei, o discurso a respeito do valor estético da marca é recorrente. Luisa, uma jovem entrevistada, se refere às suas tatuagens como "presentes para o corpo". Ela também diz:

" A tatuagem pra mim é um adorno, um adorno lindo... que nem brinco ou colar. Eu não passo quase batom, mas tô sempre pintando o cabelo. É uma vaidade! E tatuar também tem disso, é um jeito de ficar mais atraente." (Luisa, 23 anos)

Bia, a mais jovem das entrevistadas, que se tatuou com a autorização dos pais e sob o olhar deles ( que foram com ela ao estúdio), explica sua tatuagem como uma demonstração de beleza e feminilidade:

" Fiz uma coisa delicada, com cores femininas [um Pégaso em tons de azul e rosa] e no pé, a parte do meu corpo que eu mais 
gosto. Eu acho delicado, bem feminino e bem sensual porque não é uma tatuagem vulgar" (Bia, 18 anos)

Helô, artista plástica, chama atenção para a questão estética do desenho:

"Eu pinto e por isso minha primeira tattoo foi desenhada por mim, levei ela pronta e mandei fazer nas costas porque ficava absolutamente plástico , uma beleza." (Helô, 34 anos)

A tatuagem é, em grande medida, reflexo também de uma forma particular de se relacionar com o corpo. Henrique, tio de Bia, conta que fez sua tatuagem na juventude, em uma situação bastante específica:

"Todo mundo diz que é coisa de surfistão, mas eu era isso aí mesmo. E fiz porque tava passando uma temporada no Rio, na praia, no mar e fazia 'parte do quadro' ter tatuagem. Tu vê que todo mundo nessa época começou a fazer... aí tinha no braço ou nas costas... eram os lugares valorizados." (Henrique, 43 anos)

Os próprios tatuadores associam a procura pela tatuagem com a prática de mostrar o corpo. Segundo Fábio, há uma maior procura pela tatuagem no verão. Essa tendência seria explicada por dois motivos relacionados ao fato de que, com o calor, usa-se menos roupa, deixando o corpo mais exposto:

- Os tatuados deixariam suas tatuagens mais a mostra, que vistas por nãotatuados, estimulariam a vontade de se tatuar.

- Os pretendentes a tatuados teriam preferência por mostrar de imediato suas novas tatuagens, o que seria impossível no frio.

Essa preferência de se tatuar no verão é bastante criticada pelos tatuadores. Existe inclusive uma espécie de "manifesto-propaganda" de um grupo de tatuadores de Porto Alegre, estimulando as pessoas a fazerem suas tatuagens no inverno, com os argumentos de que a tatuagem cicatriza melhor se não pegar sol ou água do mar, e de que no inverno o tatuador tem menos clientes, portanto mais tempo para fazer um trabalho melhor, e até mesmo sugerindo descontos e promoções para quem não se 
importar em manter sua nova tatuagem escondida debaixo das roupas de lã, sem ser vista, até o verão chegar.

A relação do tatuado com a tatuagem passa, assim, por um intermediário, o olhar do outro, espécie de cúmplice necessário. Esse olhar pode ser, por um lado, o da admiração, da atração. De outro, resta o olhar da desaprovação:

"Minha mãe se sentiu meio agredida quando viu minha primeira tatuagem, só que isso eu levei na esportiva. O que me magoou foi a vez que meu pai me deixou esperando no carro enquanto ia ver uns parentes... é que eu tava de "blusa de física" com as tattoos do braço aparecendo." (Zé)

A liberdade pessoal de modificar o corpo de acordo com seus desejos também esteve fortemente presente na fala dos entrevistados. Zé me conta em entrevista uma conversa que teve com a irmã quando fez sua primeira tatuagem.

"Ela ficou meio assim [a irmã]... achando que ia encrencar no meu trabalho... falei pra ela, como sempre falo, o corpo é meu e faço com ele o que eu quero... ninguém tem nada com isso" (Zé)

Karen também traz referências a "autonomia" e "liberdade" quando conversamos sobre a proibição legal de que menores de 18 anos sejam tatuados sem autorização escrita dos pais:

" Todo mundo acha meio sem cabimento ir se riscar com a mamãe ou o papai junto, mas pra menor de idade... tipo... tem que ter autorização mesmo, eu sou a favor. Depois dos 18 aí é liberado, é outra história... porque na lei tu já te manda... faz o que tu quer e tem responsabilidade dos teus atos" (Karen, 21 anos)

Convém notar que a maioria dos entrevistados diz ter feito sua primeira tatuagem com 18 anos. Bia, que aos 18 já fazia a segunda, entretanto, pediu autorização dos pais para ser tatuada mesmo sendo menor de idade. Entre os tatuadores percebo a questão do menor de idade querendo se tatuar como uma situação um tanto tensa. Certa vez, logo em uma das minhas primeiras tardes de observação no estúdio de Fábio e Marco, eles me contavam que haviam certa vez tatuado "um bando 
de guriazinhas, umas cinco", todas com a mesma tatuagem "uma joaninha vermelhinha na bunda". Lembro que eu ri e perguntei se eram assim, tão novinhas (eles haviam dito guriazinhas, afinal). Fábio exclamou "bah, muito guriazinhas!"... percebi que por um momento os dois se olharam e que Marco, acrescentou: "Ah, eram guriazinhas, pareciam muito novinhas sim... mas tinham dezoito, claro".

Quando os entrevistados falavam a respeito das motivações, e dos sentidos de suas tatuagens, eram sempre presentes conteúdos e interpretações fortemente ligados a uma idéia de subjetividade individual que se torna visível através da marca.

Se faz quase sempre presente no discurso a idéia de um "eu" que se expressa através do desenho na pele. Antônio fala, a respeito do arrependimento de alguns de terem se tatuado:

"...claro que tem gente que arrepende de se riscar $6 . .$. mas tem que fazer algo que tenha muito a ver contigo, que tenha a tua cara, que seja tu... aí não se arrepende nunca. Eu sei que tu muda...quanto mais tiver a ver com as coisas tuas que não mudam, melhor..."

(Antônio)

O tatuador também toca do assunto, através de sua experiência profissional. Ele me conta em uma conversa informal no estúdio que "as pessoas querem tatuagens com significado pra elas, que tenham significado na vida ou pelo menos no momento que estão vivendo".

Luisa me explica o dragão que tem tatuado:

" ...ele traz força, uma força que eu tinha mas não conseguia pôr para fora (...) meu signo é dragão [no horóscopo chinês], dragão eu já era".

A força do dragão, nas palavras de Luisa, parecem também ligadas a masculinidade:

"Poucas mulheres tatuam dragão, homem tatuar dragão é mais comum (...) mas eu acho que mulher também tem que ser forte, por isso que eu fiz. E fiz dois." (Luisa)

${ }^{6}$ Forma bastante usada para dizer "tatuar-se". 
Poderia-se falar, assim, em uma subjetividade, uma interioridade do sujeito que deve ser expressada pela tatuagem, ou ainda, que essas duas dimensões estejam no mínimo "em sintonia".

No que diz Luisa, mais do que uma valorização da interioridade, poderíamos pensar em uma necessidade de tornar essa interioridade (esse "eu" subjetivo) exterior, para que ela pudesse tomar forma. A subjetividade, além de expressa, é construída na sua exteriorização. É preciso que o dragão seja colocado "para fora" a fim de tornar-se dragão.

A tatuagem serviria portanto também para marcar no mundo "de fora", aos olhos dos outros, uma diferenciação interna dos sujeitos, uma vez que a própria noção de subjetividade implica que o sujeito seja "único", em suas características e particularidades. Diz um entrevistado:

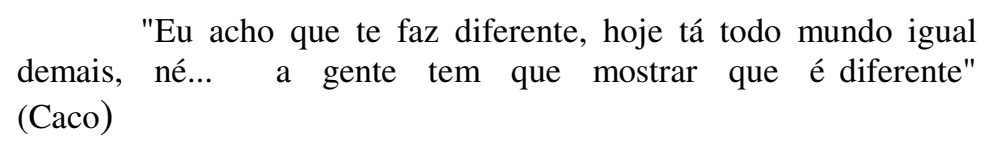

Luisa também fala em "diferenciar", em tornar singular:

"É uma marca realmente, e eu sou única com ela"

Ainda assim conta, momentos depois:

"Quando voltei ao estúdio do Allegro pra fazer a segunda tattoo ele tava riscando ${ }^{7}$ um índio num cara, o mesmo índio, o mesmo que tinha feito na minha perna"

(Luisa, 23 anos)

\section{Marcas do colorido da cidade}

A partir das vivências em campo, tanto de observação no estúdio de tatuagem quanto das entrevistas com as pessoas tatuada, é possível situar a tatuagem no grupo estudado como uma prática que diz respeito a uma linguagem urbana, uma forma de viver na cidade.

Nos aproximamos portanto do que Gilberto Velho (1994) chama de "especificidade da vida metropolitana", onde se verifica a coexistência de uma multiplicidade de experiências, tradições e costumes. Georg Simmel, quando trata do

\footnotetext{
${ }^{7}$ tatuando
} 
homem blasé, um dos tipos, faz referência a um quase infinito número de estímulos contrastantes que, impostos a ele, gerariam essa atitude de quase indiferença (SIMMEL:1987). A atitude blasé, como uma espécie de defesa, permitiria a coexistência dessa multiplicidade de valores, gostos e modos de vida, mesmo em um espaço geográfico limitado.

O habitante da grande metrópole viveria assim, em permanente contato com diferentes mundos e regiões morais (PARK apud VELHO:1994a). Como resposta a essa pluralidade de estímulos e possibilidades os sujeitos encontrariam duas alternativas básicas, uma, situada em um desejo de individualização radical, permitiria a ele mover-se e manipular mundos e dimensões diversos, e por vezes até contraditórios. (VELHO:1994) Do outro lado, restaria a alternativa da "desindividualiszação", através da adoção de estereótipos fechados, como "a dona de casa", "o punk", "o mauricinho", "a executiva", "o crente". Tais estereótipos seriam baseados nas vivências dos sujeitos, como na participação em certos grupos ou instituições, na família, na carreira, na opção religiosa ou no pertencimento étnico, sendo tomadas como mais ou menos fundamentais na constituição de suas identidades.

Gilberto Velho (1994b) também propõe, entretanto, que essa circulação entre grupos se dá cada vez mais na sociedade contemporânea de forma fluída, sem cair na simplificação estereotipada da identidade formada unicamente por um único traço de pertencimento e sem, ao mesmo tempo, pender para a noção de individualização e indiferença com relação aos múltiplos estímulos vivenciados socialmente. É nesse sentido que ele fala em potencial de metamorfose, ou seja, na possibilidade de interagir e participar de grupos diferenciados ocupando neles papéis também diferenciados. O conceito de metamorfose que o autor propõe, no entanto, sugere transformação com permanência, uma vez que o estado anterior de alguma forma permanece presente.

Em "O urbanismo como modo de vida" Wirth também fala da heterogeneidade cultural da metrópole (WIRTH:1987), no que concerne a interação entre uma imensa variedade de "tipos humanos" e de grupos sociais. Segundo ele, o homem urbano tem uma mobilidade social incomparável, podendo facilmente flutuar entre os diferentes grupos que compõe a estrutura social da cidade. 
O transito entre diferentes grupos, onde os sujeitos ocupam papéis sociais diferenciados pode ser percebido na fala dos entrevistados quando esses se referem, por exemplo, ao jogo do mostrar-esconder a tatuagem. No ambiente de trabalho, por exemplo, ela pode estar visível ou não:

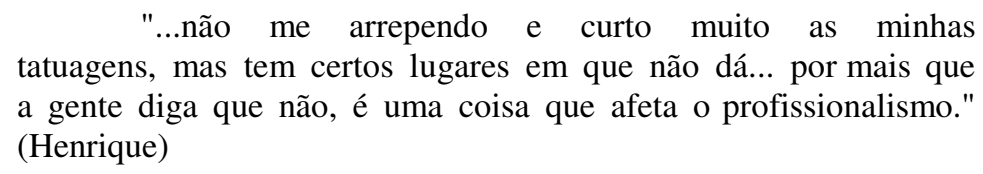
a gente diga que não, é uma coisa que afeta o profissionalismo." (Henrique)

"Minha mãe, e olha que ela já acostumou com as minhas tattoos, sempre diz que não contrataria uma pessoa com tatuagens ou piercings muito visíveis. Mas é porque ela tem uma loja, e quando se trabalha com atendimento, pode ter cliente com preconceito." (Caco)

Antônio, apesar de se considerar um aficionado pela tatuagem, pondera sobre seu futuro profissional antes de fazer as suas:

\footnotetext{
" Ter tattoo ou não ter tanto faz. Deixar que saibam é que muda tudo. Vou ser psicólogo, não posso ter uma coisa muito visível" (Antônio)
}

Fazendo questão de dizer que no lugar onde trabalha convive com outras pessoas tatuadas, Luisa acha que nunca teria problemas quanto as suas:

\author{
" Eu trabalho com pessoas ligadas a arte, não tem stress \\ com essas coisas. Todo lá no trabalho viu as minhas \\ tatuagens e nunca duvidaram da minha competência por \\ causa delas" (Luisa, 23 anos)
}

Mais de uma vez Luisa fez referência durante a entrevista ao seu grupo de trabalho como "pessoas ligadas a arte", ou "envolvidas com cultura" e ainda como "com espírito alternativo", reivindicando em certos momentos para si uma identidade semelhante.

Helô, também inclui a si própria na categoria de "pessoas ligadas a arte". Quando nos conhecemos, entretanto, lembro bastante bem dela contar que era 
formada em artes plásticas mas era professora e casada. Mais tarde, quando falamos de casamento, ela imediatamente se apropria de outra categoria, a do "tradicional", se dizendo "muito tradicional pra essas coisas", e deixando por alguns momentos de lado o rótulo do "espírito alternativo".

Por vezes, entre os homens do grupo de pessoas tatuadas que entrevistei, percebia certa necessidade de afirmar mais do que o "espírito alternativo", e já certa identidade em torno de um modelo de comportamento desviante (BECKER: 1977). Em conversa que aconteceu no estúdio, Fábio, Marco e Antônio falavam de drogas e de suas "aventuras" em batidas policiais. Contavam de como e quantas vezes haviam "escapado duma", e como tinham conseguido "enganar os porcos $8 "$.

Quando Marco conta em seguida de um episódio em que a casa de seus pais foi assaltada, parece flutuar com perfeição para o "outro lado". Os assaltantes, eles sim agora são os bandidos. A polícia deixa também de ser referida como "os porcos", transformando-se em "os guardas".

Maffesoli também vê a sociedade ocidental contemporânea como como palco de mudanças no âmbito das identidades e das relações sociais. Segundo ele viveríamos atualmente uma época de retorno às "tribos", uma espécie de "tribalização" que, entretanto, se caracterizaria pela ambivalência, pela instabilidade e câmbio (MAFFESOLI:2000) O coeficiente de pertencimento não é mais absoluto, e as coisas ultrapassariam cada vez mais uma lógica binária de identidade para tornarem-se sobretudo "trans", "pluri" e "meta".

Essas tribos, entretanto não estariam configuradas por uma lógica e organização racional e político, como por exemplo, a ajuda-mútua. Ao contrário, seriam o que Maffesoli chama de "comunidade afetivas", unidas muito mais por uma socialidade, um desejo de estar junto, um costume, um compartilhar momentos e fazer coisas juntos sem uma finalidade utilitária específica.

O autor diz, entretanto, que essas tribos urbanas apesar de fluidas estão sempre buscando índices comuns de pertencimento, rituais como, por exemplo, a freqüência comum a determinados, bares, lojas, ruas ou mesmo locais de consumo cultural, como teatros, cinemas e casas de espetáculo.

\footnotetext{
${ }^{8}$ Gíria pejorativa poara se referir aos policiais...
} 
Nesse sentido, é possível encontrar elementos comuns de pertença entre os que faziam parte da rede de entrevistados. Ainda que participem de diferentes círculos de relações a um só tempo e transitem por campos de valores bastante distintos, ocupando em cada um deles papel diferenciado, há semelhanças no que concerne hábitos, gostos e até mesmo seu trânsito por lugares da cidade.

Mesmo que de início não pensasse em termos de uma delimitação geográfica dos espaços da tatuagem no interior da rede de pessoas que entrevistava, consigo perceber agora um corte espacial. O recorte de classe, de idade, e de estilos de vida mais ou menos parecidos nos dá pistas, longitudes e latitudes. Seria possível desenhar assim uma região freqüentada (ainda que nem sempre habitada) por essas pessoas tatuadas com as quais mantive contato.

O estúdio que observava no princípio do trabalho localizava-se na Avenida Independência (entre as ruas Garibaldi e a Santo Antônio) e a poucas quadras dali, na mesma calçada, outros estúdio conhecido. Um, mais recente, e com menos tradição, localiza-se na rua Felipe Camarão, bastante próximo aos outros.

A Avenida Osvaldo Aranha também entraria na planta, cujo limite inferior (considerando-se a Av. Independência como superior) seria o parque da redenção, graças ao brique e ao auditório Araújo Viana (na frente do qual algumas entrevistas foram realizadas). Incluo a região do gramado em frente ao auditório, usando no mapa as mesmas cores.

Dentro dos limites Avenida Independência - Avenida Osvaldo Aranha, percebo a Lancheria do Parque, localizada na Avenida Osvaldo Aranha, como lugar frequientado por praticamente todas as pessoas que entrevistei. Ainda que meu contato tenha se estabelecido fora dali, era quase sempre referência nas falas, assim como o Bar do João. Aqueles que não se conheciam diretamente diversas vezes se reconheciam nas fotografias que eu levava, dizendo por exemplo "acho que já vi esse cara, conheço ele da Lanchera" 9 ", ou "encontrei a menina do índio na perna ontem na Osvaldo", como me disse um dos tatuadores do estúdio em que eu realizava a observação, que já havia visto fotografias de Luisa - a menina do índio na perna anteriormente. Como freqüentadora esporádica da Lancheria do Parque, passei a

\footnotetext{
${ }^{9}$ Lancheria do Parque, localizada na Avenida Osvaldo Aranha
} 
encontrar sempre lá alguma das pessoas que havia entrevistado. Em uma mesma noite, um Domingo do começo do mês de agosto, cheguei a encontrar cinco pessoas com as quais havia mantido contato, três tatuados entrevistados e os dois tatuadores.

Quando falo em elementos comuns que comporiam um estilo de vida semelhante entre os entrevistados, incluo, além dos lugares da cidade freqüentados, tipo de lazer, gostos musicais e rotina de vida. O gosto pelo reggae e por assistir os shows de grupos musicais (nesse caso de reggae, rock, rap ou mpb) realizados em espaços públicos da cidade (Auditório Araújo Viana, Usina do Gasômetro, Jardim Botânico, entre outros) era bastante recorrente. A maioria deles também dizia freqüentar a Usina do Gasômetro nos dias de Mix Bazzar ${ }^{10}$, para comprar roupas, cds, "ir às festas do Mix" (que acontecem à noite, no mesmo local da feira), ou "simplesmente circular".

Nesse sentido seria possível falar em um habitus, enquanto um sistema de disposições socialmente constituídas (BOURDIEU:1998) que funcionariam como princípio gerador e unificador das práticas e orientações. Acho difícil nesse caso específico aplicar a noção de habitus centrada unicamente na questão de classe social. Mesmo que possamos argumentar que todos os entrevistados situam-se em camadas médias da sociedade, e que seus hábitos de consumo e práticas cotidianas estão ligados a um certo nível econômico, como no caso da própria tatuagem (o valor da hora de trabalho de um tatuador gira em torno de cem reais), vemos aí um forte recorte geracional.

\section{Mercado da tatuagem como mercado de bens simbólicos}

Atualmente, a prática de tatuar o corpo, impulsionada pela moda (ou por modas?) e pela por sua maior aceitação por parte da sociedade em geral, aumentou muito sua abrangência. É curioso verificar que, nas sociedades ocidentais, antes endossando e reforçando características de grupos específicos e até mesmo marginais -marinheiros, presidiários, punks - tenha atingido hoje em dia um público tão diversificado. A exemplo disso temos sua forte presença, nos últimos meses, em duas publicações brasileiras conhecidas dirigidas ao público feminino, e com relativa influência na propagação de "modismos" e hábitos de consumo.

\footnotetext{
${ }^{10}$ Feira de variedade que ocorre periodicamente na cidade
} 
Na revista Nova do mês de novembro de 2000, temos uma nota ocupando praticamente uma página inteira da sessão "Repórter de Beleza". O título da matéria, "Detalhe excitante", permite ter uma idéia de seu conteúdo: a tatuagem como forma de expressar sensualidade. Traz ainda uma enquete realizada pela revista, revelando o que pensam os homens a respeito desse tipo de marca nos corpos femininos. Ainda na mesma edição, na sessão "Notícias da Redação", mulheres que trabalham na produção da revistas mostram suas tatuagens, ou, como diz o texto da redatora, "suas marcas sexy".

Na Revista Elle do mês se setembro de 2000 também há uma reportagem a respeito do tema. Nesse caso, uma matéria grande, de 4 páginas, e com fotografias. $\mathrm{O}$ título da reportagem também é bastante sugestivo: "Tatuagem, você ainda vai ter uma". O texto, por sua vez, traz entrevistas com mulheres tatuadas, com tatuadores e até mesmo com uma psicóloga e uma antropóloga que dão seus pareceres sobre o assunto.

A tatuagem chega ao público, assim, como uma moda e uma mercadoria a ser consumida. Tal situação é facilmente verificada se levarmos em conta as relações que se estabelecem entre os tatuadores, fornecedores de serviços, e com seus clientes. O mercado da tatuagem possui regras formalizadas, como por exemplo o acordo e consenso no estabelecimento de um valor comum (pelo menos indicativo) da hora de serviço dos tatuadores. O preço de uma tatuagem também é influenciada por uma relação de oferta e demanda. No inverno, por exemplo, quando a procura é menor, é possível obter descontos. ${ }^{11}$

A caracterização da tatuagem enquanto mercadoria é entretanto permeada por uma matriz simbólica, uma vez que, mais até do que quando se compra uma roupa ou outro bem material, com "produto" tatuagem está sendo comprado um estilo de vida, um status, e uma série de desejos que, através do "ter", conformam os sentidos da imagem do "ser".

Bourdieu diz, a respeito das escolhas e preferências que envolvem o consumo de bens culturais, que funcionam como que marcadores de classe (BOURDIEU:1998b). Os bens consumidos, assim, podem ser associados a escolhas

\footnotetext{
${ }^{11}$ ver discussão a respeito no capítulo IV
} 
que, não materiais, se materializam na posse e no uso do objeto. Essas escolhas e preferências denotam, entretanto, não apenas uma "posição de classe" no sentido econômico (FEATHERSTONE:1995), enfatizando diferenças de estilo de vida e demarcando relações sociais de reconhecimento. Bourdieu se refere às "marcas de distinção" como forma de situar-se na estrutura social e de constituir-se frente a si mesmo e aos outros (BOURDIEU:1998). Segundo ele, a moda seria grande potencial para ser uma dessas estratégias de distinção, na medida em que o vestuário combina qualidades de individualização e de imitação (SIMMEL apud BOURDIEU:1998). Ela permite assim marcar simbolicamente a distinção, porque permite aderir sucessivamente a diversos signos distintivos e, ao mesmo tempo, confere uma marca comum aos membros de um grupo particular.

Em se tratando do grupo de entrevistados, mais do que a mera opção de se tatuar, estão em jogo uma série de atitudes e apropriações simbólicas da imagem do "ser tatuado, gostar de tatuagem" na definição de um status e de uma posição dentro do grupo e em relação aos que estariam fora dele. No discurso dos próprios tatuadores é possível perceber um desejo de diferenciar os tatuados "autênticos" e "nãoautênticos", de acordo com o envolvimento e conhecimento destes no universo da tatuagem. Marco, em uma conversa informal no estúdio, comenta a respeito dos "não autênticos", dos que "não vivem para a coisa", ou "fazem porque é moda", fazendo muitas vezes comentários irônicos a respeito da postura de alguns clientes que o procuram e que, por exemplo, na primeira visita ao estúdio perguntam, além do preço e de detalhes técnicos, informações sobre como é possível remover a tatuagem.

O conhecimento mínimo das técnicas e dos tatuadores mais consagrados também é uma das características que define a "autenticidade" e o grau de envolvimento com o meio.

Helô, contando a respeito de suas várias tatuagens (ela se diz uma "colecionadora"), traz à tona algumas idéias:

"São artistas [os tatuadores]. Tem gente que compra jóia assinada, acho legal... mas eu tenho jóias assinadas na minha pele" (Helô) 
Caco segue a discussão, contando que geralmente deixa que o próprio tatuador escolha o que quer tatuar em seu corpo.

"...aprendi a sentar na cadeira [do tatuador] e dizer pra ele ir em frente, passei a acreditar no trabalho dos caras... tem que deixar que façam os desenhos do jeito deles... free hand ${ }^{12}$ tem muito mais valor" (Caco)

Durante o mês de outubro acompanhei um grupo de tatuadores a uma convenção internacional de tatuagem que aconteceu em São Paulo. Lá pude observar o valor dado a esse tipo de tatuagem free hand dentro do grupo de profissionais. Diversas vezes me mostraram braços e pernas de outros tatuadores (ou simplesmente tatuados), onde se via estampado o trabalho "livre" de tatuadores estrangeiros consagrados. Eles diziam: "olha isso, que fantástico!", e acrescentavam, decepcionados com meus comentários que não ultrapassavam um julgamento estético amador ou algum comentário sobre as cores: "Isso é um desenho do Sabado [que vim a saber ser um famoso tatuador], dá vontade de arrancar a pele e costurar em mim, é uma perfeição".

Parece também ser bastante comum, entre os aficionados pela tatuagem, profissionais ou não, o desejo de ter uma tatuagem feita por tal ou tal "grande mestre". Antônio, de Porto Alegre, conta em entrevista que viajou à São Paulo para fazer seu primeiro desenho:

\footnotetext{
"Tinha que ser com o Edgar [tatuador paulista relativamente conhecido] porque eu sempre via os trabalhos dele em revistas e curtia muito. Fui de avião, ele me tatuou e voltei no mesmo dia."(Antônio)
}

Karen, sua namorada, que também se tatuou com Edgar durante a convenção, acrescenta:

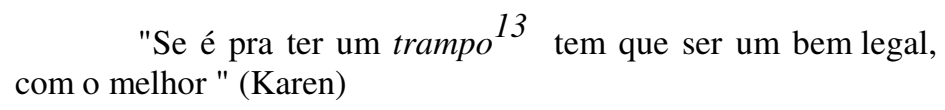

12 Tipo de tatuagem em que o tatuador desenha a mão livre, sem copiar.

${ }^{13}$ Expressão usada entre alguns tatuadores ou tatuados relativamente envolvidos no meio 
A relação simbólica estabelecida a partir do uso da marca, nesse caso, só é eficaz se junto a ela forem incorporadas outros hábitos e formas de consumo como, por exemplo, revistas de tatuagem, livros, conversas freqüentes com tatuadores profissionais ou até mesmo viagens para acompanhar feiras e convenções.

Além desses "saberes", o consumo de outros bens estão associados ao uso da tatuagem, também reforçando os sentidos expressos através dessa. O tipo de roupa, por exemplo, assim como de cabelo (cor, corte e penteado), tem um características bem marcadas, mesmo que transitando por diferentes estilos. Featherstone fala da metrópole contemporânea repleta dessa diversidades de estilos que podem existir mesmo sem coerência interna (FEATHERSTONE:1995). Segundo ele nossa época não seria, como dizem alguns autores, uma época sem estilo mas, ao contrário, formada por esses estilos diferentes, misturados nessa liquefação de signos.

Pensando nos desenhos que encontramos na pele das pessoas pelas ruas da cidade, temos também a coexistência de elementos muito diferentes, sobretudo distanciados de nossa cultura (o exótico) e incorporados livremente. Assim, Zé pode exibir o que ele chama de "máscara balinesa" em um braço, um motivo relacionado aos índios norte-americanos em outro, e uma tatuagem considerada "tradicional", como uma lady lucky ${ }^{14}$ nas costas. Observando alguns cartões de estúdios de tatuagem de Porto Alegre e do resto do Brasil vemos com bastante clareza essa "colcha de retalhos" de elementos distintos e distanciados. Vários deles fazem referência à sociedades tradicionais, indígenas, africanas ou indianas. Outros trazem motivos religiosos (CORAZON) ou mitológicos (LEDS), com deuses escandinavos ou druidas.

Da mesma forma, os tatuados podem exibir aparências diferenciadas e muitas vezes contrastantes, com diferentes elementos incorporados, como os cabelos rastafari de Caco, os vestidos hippie de Luisa ou as roupas pretas e pulseiras de couro de Karen. Há, de qualquer forma, uma preocupação visível com a moda, com o look, uma das tendências apontadas por Featherstone como parte de um processo de diferenciação cultural no qual ele situa a "nova onda de flâneurs urbanos" (FEATHERSTONE:1995). É esse estilo melée o tipo de estética promovido por

\footnotetext{
${ }^{14}$ senhorita sorte... normalmente uma pin- up com os seios a mostra, apenas cobertos por trevos da sorte ou duas bolas de sinuca.
} 
algumas revistas de moda, como a publicação britânica The Face e, no Brasil, a revista Mundo Mix Magazine, cujo lançamento é relativamente recente.

Segundo Featherstone a contemporaneidade seria marcada por essas características que formam um desejo de estetizar a vida cotidiana. Tal estetização implicaria sobretudo na idéia de que a arte, saindo do âmbito do "sagrado" e de um campo específico, se profaniza e populariza, ao mesmo tempo que a realidade recebe uma "aura" artística. Haveria assim uma dedicação à estilização da vida, a "transformar a vida em uma obra de arte", movida por uma postura ativa em relação a manifestação de um estilo de vida.

Tal postura, encabeçada por uma atração pelo estilo "alternativo", "boêmio" e "romântico", faz lembrar o que fala Bourdieu das mudanças sociais que se desenrolaram no campo artístico no século XIX (BOURDIEU:1992). O autor diz que, junto ao processo de legitimação do campo artístico como campo autônomo, havia a predisposição à invenção do estilo de vida do artista como um estilo boêmio de se viver. Surge assim a art-de-vivre, a tendência em transformar a vida em uma das belas-artes, um evento em si que, pleno de fantasia, diversão, amor em todas as suas formas, música e ironia se distingue da rotina da vida da burguesia da época.

\section{Considerações Finais}

A um passo do século XXI somos parte de uma era marcada por um veloz e significativo progresso tecnológico e científico. Esta velocidade não se resume à criação de tecnologias, mas a sua propagação. Hoje, praticamente em qualquer lugar do planeta, se tem acesso a todo o tipo de mercadoria, informação. Mais do que isso, a circulação de bens simbólicos, moda e produção cultural marca o cotidiano de qualquer grande metrópole de qualquer parte do mundo atualmente.

É nesse contexto que foi pensada a cidade de Porto Alegre enquanto locus de coexistência da heterogeneidade cultural que marca a vida urbana contemporânea. Lidamos aqui, portanto, com diversos personagens urbanos, cuja trajetória, como vimos, é marcada pelo colorido dessa pluralidade de vivências e interações.

No grupo estudado, em especial, focalizamos questões importantes, apontadas por alguns autores como características da contemporaneidade, como a questão dos múltiplos pertencimentos, da variedade de papéis atribuídos aos indivíduos 
cotidianamente, da noção do sujeito marcado pela tensão entre individualização e incorporação ao grupo, do espectro simbólico que paira sobre as relações de consumo, e da estilização da vida, dando papel fundamental à estética e ao lúdico nas sociedades atuais.

A prática da tatuagem seria, assim, marcada por todas essas dimensões e, a um só tempo, seria a marca delas sobre os corpos dos sujeitos. A tatuagem entre o grupo estudado é portanto, a forma de expressão e o reflexo dessa forma metropolitana, ocidental e contemporânea de viver. Como superfície de escrita dos símbolos da cultura, o corpo traz assim, a flor da pele, as pistas para que possamos melhor compreendê-la.

\section{BIBLIOGRAFIA}

BASTIDE, Roger. Técnicas de Repouso e de Relaxamento (um estudo transcultural). In: QUEIROZ, M.I. Roger Bastide. São Paulo: Ática, 1983. Pg 88-10

BARREIRA, Solange. O charme da tatuagem marca para sempre. Revista Galileu. Ano 8. No. 86. Setembro de 1998. Pg. 54-61.

BECKER, Howard S. Uma teoria da ação coletiva. Rio de Janeiro: Zahar 1977. BOREL, France. Le vêtement incarné. Mesnil-sur-1'Estrée:. Éditions Calmann-Lévy. 1992. BOURDIEU, Pierre. El Oficio del Sociólogo. México: Siglo XXI, 1985.

BOURDIEU, Pierre. A economia das trocas simbólicas. São Paulo: Perspectiva. 1998 a.

BOURDIEU, Pierre. O poder simbólico. Rio de Janeiro: Bertrand Brasil. 1998b. BOURDIEU, Pierre. Les regles de l'art. Paris: Seuil. 1992. CAMPHAUSEN, Rufus C. La tribù del tatuaggio. Milão: Lyra Libri. 1999.

CARUCHET, William. Le tatouage ou le corps sans honte.. Paris: Éditions Séguier, 1995.

CASTRO, Celso. Homo Solitarius. In: Cadernos de Campo. USP. São Paulo. CHIZZOTTI, Antonio. Pesquisa em Ciências Humanas e Sociais. São Paulo:Cortez, 1998.

CLASTRES, Pierre. A sociedade contra o Estado. Rio de Janeiro: Francisco Alves. 1990. Capítulo X. Da Tortura nas Sociedades Primitivas. Pg 123-131. DE CERTEAU, Michel. A Invenção do Cotidiano. Petrópolis: Vozes. 1996. DUARTE, Luis Fernando Dias. \& LEAL, Ondina Fachel. (org) Doença, Sofrimento Perturbação: perspectivas etnográficas. Rio de Janeiro: Fiocruz. 1998. DUMONT, Louis. Homo Hierarchicus. São Paulo: Edusp. 1997

DUMONT, Louis. O Individualismo: uma perspectiva antropológica da ideologia moderna. Rio de Janeiro: Rocco. 1985. 
ELIAS, Norbert. A Sociedade dos Indivíduos. Rio de Janeiro: Zahar. 1994

FEATHERSTONE, Mike. Cultura de Consumo e Pós-Modernismo. São Paulo: Studio

Nobel. 1995.

GEERTZ, Clifford. A Interpretação das Culturas. Rio de Janeiro: LTC. 1989.

GONÇALVES DA SILVA, Vagner. "Abertura". In: Antropologia e seus

Espelhos. São Paulo: FFLCH-USP. 1994

HEERTZ, Robert. " A preeminência da mão direita". In: Religião de Sociedade. $\mathrm{N}^{\circ}$ 6, 1980. Pg 99-128.

KRAKOW, Any. The total tattoo book. Nova Iorque: Time Warner. 1994.

LE BRETON, David. L'Adieu au corps. Paris: Éditions Métailié. 1999.

LE BRETON, David. Anthropologie du corps et modernité Paris: PUF.1998

LE BRETON, David. (org). Usages culturels du corps. Paris: L’Harmattan.

LÉVI-STRAUSS, Claude. Tristes Tropiques Paris: Pocket. 1997a

LÉVI-STRAUSS, Claude. Introduction à l'ouvre de Marcel Mauss. In:MAUSS, Marcel. Sociologie et Anthropologie. Paris: PUF. 1997b

MAUSS, Marcel. Les techiniques du corps. In: Sociologie et Anthropologie.

Paris:PUF. 1997 a. Pg 363-386.

MAUSS, Marcel. Une catégorie de l'ésprit humain: la notion de personne celle de "moi". In: Sociologie et Anthropologie. Paris: PUF. 1997 b Pg. 331-362.

MAERTENS, Jean-Thierry. Le dessein sur la peau. Paris: Aubier Montagne. 1978.

MAFFESOLI, Michael. O Tempo das Tribos. Rio de Janeiro: Forense

Universitária. 2000.

MARQUES, Toni. O Brasil tatuado e outros mundos. Rio de Janeiro: Rocco. 1997.

MENDES DA SILVA, Maria Albuquerque. As tatuagens e a criminalidade

feminina. In: Cadernos de Campo. Ano I. No. I. FFLCH- USP. 1991. Pg 5-26.

MIFFLIN, Margot. Bodies of subversion: a secret history of women and tattoo. Nova Iorque: Juno Books. 1997

PUELLES, Vicente Muñoz. Los Tatuajes, Valencia: Editorial La Mascara. 1998. RODRIGUES, José Carlos. O Corpo na História. Rio de Janeiro: Fiocruz.1999

ROUPENNE. Margareth B. Dis moi Qui tu tatoues... In: TRAVERSES No. 7. Maquiller. Paris: Editions Minuit. Fevereiro de 1977. Pg 145-151.

RUBIN, Arnold. Marks of Civilization. Los Angeles: Museum of Cultural History, University of California. 1988.

SCHIFFMACHER, Henk. 1000 Tattoos. Colônia: Taschen. 1996.

SIMMEL, Georg. A metrópole e a vida mental. In: VELHO, Otavio (org) O fenômeno urbano. Rio de Janeiro: Ed. Guanabara. 1987. Pg. 11-25.

STEWARD, Samuel M. Bad boys and tough tattoos. Nova Iorque: Harrington Park Press. 1990.

TOURAINE, Alain. Critique de la Modernité . Paris: Fayard. Collection Le Livre de Poche. 1992

VELHO, Gilberto. Individualismo e Cultura. Rio de Janeiro: Zahar 1994a

VELHO, Gilberto. Subjetividade e Sociedade. Rio de Janeiro: Zahar 1989a

VELHO, Gilberto. Projeto e Metamorfose. Rio de Janeiro: Zahar. 1994b

VELHO, Gilberto. Desvio e Divergência. Rio de Janeiro. Zahar. 1989b 
VIVEIROS DE CASTRO, Eduardo B. A fabricação do corpo na sociedade xinguana. In: Sociedades Indígenas e Indigenismo no Brasil. Rio de Janeiro : Marco Zero. Pg 40-49.

WIRTH, Louis. O urbanismo como modo de vida. In: VELHO, Otavio. $O$ fenômeno urbano. Rio de Janeiro: Ed. Guanabara. 1987. Pg. 90-113. 
Iluminuras - Banco de Imagens e Efeitos Visuais, PPGAS / UFRGS, 2001 - Número 23 